\title{
Effect Of Tax Revenue On Foreign Debt In Nigeria
}

\author{
Nwaobia, A. N. (PhD., FCA) nwaobiaa @babcock.edu.ng; \\ Ogundipe, S.A. (PhD., FCIB); ogundipea@ babcock.edu.ng, \\ Adejumo, R.I. (M.Sc, ACA) rotimi4ever2007@ yahoo.com.
}

DOI: $10.29322 /$ IJSRP.11.10.2021.p11829

http://dx.doi.org/10.29322/IJSRP.11.10.2021.p11829

\begin{abstract}
Debt is a salvaging factor to cushion the effect of recurrent budget deficit, a connecting bridge for the gap between revenue and expenditure as well as means of financing sustainable growth in an economy. However, debt profile both domestic and foreign continues to increase in Nigeria without appreciable performance in economic development, hence this study examined the effect of tax revenue on foreign debt. The study made use of ex post-facto research design, and a 39-year time series data (1981-2019) sourced from CBN Statistical Bulletin 2019 and FIRS annual reports were used. The data were adjudged valid and reliable having being appropriately validated by the relevant agencies. Data analysis was done using both descriptive and inferential statistics. Findings from the study revealed that tax revenue significantly affected foreign debt in Nigeria $\left(\right.$ Adj. $R^{2}=$ $0.463, \mathrm{Rn}$-sqd $=60.61, \rho=0.00)$. It is recommended that appropriate policy mix and setting of achievable measures in exploring several opportunities to widen the tax base should be focus of Nigerian government as current level of tax revenue is not sufficient enough to cushion the rise in the nation's foreign debt profile.
\end{abstract}

Index Terms- Domestic debt, Foreign debt, Government expenditure, Non-oil revenue, Oil revenue.

\section{INTRODUCTION}

$\mathrm{D}$ ebt in whatever form can be incurred by either individual, corporate organization or government of any country of the world in order to carry out all her responsibilities and where revenue is not enough to meet developmental needs, government has to borrow. Ogunjimi, (2019) refers to debt as the money sourced outside an organization which is not contributed by its owners and does not in any other way belong to them. Hence, the act of borrowing creates debt which is a liability represented by a financial instrument sourced from another institution.

Uguru (2016) posited that a country can also borrow in the short-term from external sources to finance current account deficits arising from external disturbances in order to shore up liquidity position in the future. Odo, Igberi and Anoke (2016) opined that foreign borrowing is desirable and necessary to accelerate economic growth, provided that they are channeled to increase the productive capacity of the economy and promote economic growth and development. This will only be effective if the borrowed fund as well as tax revenue is well utilized for the productive activities that they were meant for. However, in Africa and its regions according to OECD (2019), the unstructured system of the economy has been the major challenge in generating sufficient fund for financing sustainable growth.

Further, Tajudeen (2012) posited that countries borrowings can be categorized into: macro and micro economic reasons such as; higher investment, higher consumption (education and health) or to finance transitory balance of payments deficits to lower nominal interest rates abroad, lack of long-term credit, or to circumvent hard budget constraints. This implies that governments borrow in addition to revenue generated from taxation and other services with aim to boost economic growth and foster development, however, once an initial stock of debt grows to a certain threshold, servicing them becomes a burden, and countries find themselves on the wrong side of the debt

National debt can be domestic or foreign, gross or net, marketable or non-marketable, short term, medium term or long term, interest-bearing or non-interest bearing. Prior to SAP era, Nigeria's debt obligation which was mostly domestic debt stock has been on a sustainable threshold; hence, Asagunla and Agbede (2018) posited that Nigeria's debt/Gross Domestic Product (GDP) percentage as at 1980 was $10.69 \%$ but by 1993 , this ratio has increased to $181.88 \%$ due to the global oil glut of that period that affected the country's revenue and for the first time since independence Nigeria dipped into recession in 2015. Also, DMO, (2015) reported that between 2015 and 2018, the stock of foreign debt increased significantly as a result of currency depreciation and other factors due to the depreciation of currencies in which debt is expressed, for example, the depreciation of the dollar against the British pound for instance, meant that debt held in Pound Sterling when expressed in dollars would increase even when other parameters of the debt remained unchanged.

The debt forgiveness Nigeria enjoyed from the Paris Club in 2006 put the country debt stock back to its sustainable path, after which the government started another set of uncontrolled debt accumulation which put Nigeria's current debt stock at $72 \%$ of 2021 budget, thus leaving little capacity to fund the nation's infrastructure. Hence, experts are currently debating the current trend in accumulation of external borrowings in recent times (Asagunla \& Agbede, 2018). Thus Udeh (2013), opined that settlement of excessive foreign debts hindering the growth of most highly indebted poor countries (HIPCs) has led to the embracing of numerous initiatives ranging from debt rearrangement to absolute repudiation. In the same vein Bakare (2011), opined that the need for external borrowing to foster economic growth and development is not an issue, but the challenge is the misapplication of such borrowed funds recklessly and non- 
directional as it has become a norm and issue of politics without major capital projects in mind when foreign loans are contracted. Meanwhile, taxes constitute a major source of revenue to governments in both the developed and developing countries. Even with the discovery of oil in Nigeria, tax revenue still remained a major source of revenue to successive governments over the years as the proportion of tax revenue to total revenue was $26 \%$ in $2010,52 \%$ in 2016 and $44 \%$ in 2017 (CBN, 2017). The problem with administering the tax has been lacking of invoicing and record keeping by businesses, and the existence of informal activities not covered by the tax system (Somorin, 2015). The contribution of VAT in reducing Nigeria's dependence on oil revenue has not been much being still at single digit percentage in spite of the government's efforts to ensure its effectiveness at the initial stage, by certain amendments in the existing tax structure to reduce general tax burden and encourage compliance (Somorin, 2015). However, the concept of taxation has been a concern globally as it affects every economy irrespective of national differences. Therefore, taxation is a powerful tool of economic reform and a major player in every economy of the world.

\subsection{Statement of the Problem}

Debt is expected to be a form of alternative means of developing the real sector of any economy but debt has been a disaster in major African countries due to its mismanagement and unproductive utilization (Torki, 2016). Similarly, upsurge in the external and internal debt accumulation of the country has been blamed on the persistent hike in the general price level, fiscal imbalances, excessive government spending and inadequate growth in the gross domestic product as well as the decline in public revenue since the commencement of the oil crisis of the early 1980s (Kehinde, Olanike, Oni and Achukwu, 2015). Olurounbi (2020) asserted that due to the prevailing low oil prices and accrued revenue which is threatening fiscal flexibility, Nigeria is likely to be facing tough economic choices in 2021 and the years ahead. Moreover, factors such as a resurgence in Covid-19 cases leading to a new wave of lockdowns in Europe and Nigeria, weak oil prices and deep OPEC production cuts and macroeconomic uncertainty are going to push Nigeria's public debt higher in 2021 and this will cause balance of payment (BOP) to remain in deficit and thereby force the country to rely more on foreign debts and grants to shore up its falling revenue.

Furthermore, Obatola (2014) posits that there has been a wide gap between the government and the people's expectation regarding transparent management of resources and accountability, between the tax administrators and tax payers, in communicating and explaining tax matters. This has been made more difficult because the agency in charge of administration has been different from the agency in charge of implementation which is responsible for the low revenue collection from the tax system. Therefore, the main objective of this study is to assess the effect of tax revenue on foreign debt in Nigeria. Similarly, this study focused on all levels of tax revenues being collected at federal level of Nigeria government, aggregated into oil tax revenue and non-oil tax revenue, and Nigeria's debt portfolio both local and international as at December 2019.

\section{REVIEW OF LITERATURE}

\section{Tax Revenue}

Oxford Dictionary of Accounting (2005) simply defines tax as a levy on individuals or corporate bodies by central or local government for the purpose of financing the expenditure of that government and as means of implementing its fiscal policy. The same dictionary defines fiscal policy as the use of government expenditure and tax revenue to influence macroeconomic conditions. Similarly, Molle et al., (2014) define tax revenue as compulsory levy imposed by the state on the people; hence, its implementation can be forced. In addition, payment of tax by citizens does not depend on government providing appropriate service or making any direct remuneration; hence, mobilisation of public fund to the government is usually done in form of income tax, wealth tax, inheritance tax, sales tax, or all of which are referred to as taxes.

Similarly, Oyebanji (2017) defined tax as the compulsory transfer or payment (or occasionally of goods and services) from private individuals, institutions or groups to the government. Also Obatola (2014) asserted that for tax revenue to play its role of amending economic ills for all, the following four important issues must be put to heart. First, it must be understood that tax is a compulsory contribution that flows from the citizens to the government, and this contribution is for the benefit of all. Secondly, tax imposes a general obligation to the tax payer. Thirdly, there is a presumption that the contribution of the public revenue made by tax payers may not be equal to the benefits enjoyed by the citizens. Further, a tax is not imposed on a citizen by the government as a result of services rendered to the citizens. Similarly, Oyedele (2015) recognised two purposes of taxation in developing countries to include provision of concessions and fiscal incentives as means of stimulating private enterprise, and mobilisation of resources to finance public expenditures.

\subsection{THE NATURE AND STRUCTURE OF TAXATION IN NIGERIA}

The history of taxation in any nation is as old as the political history of such nation. Taxation has been employed by various governments as fiscal policy tool to achieve economic and social objectives, such as increasing government revenue and provision of social and economic facilities, redistribution of income from the rich to the poor, redirection of savings and investment, boosting of industrialisation, export promotion, control of inflation or deflation, control of wasteful or harmful spending, protection of local industrial activities, and other social and economic objectives. The nature of taxation in any country makes up the tax system of such country. The Nigerian tax system is made up of tax laws, tax policies, and tax administration. The tax laws and policies are formulated by the legislative and executive arms of the government, respectively, while tax administration, involving the interpretation and application of the laws and policies, is carried out by relevant government agencies, such as Federal Inland Revenue Service at the federal level, State Internal Revenue Services at the state level, Revenue Committees at the local government level, and the Joint Tax Board. The challenge before the government has always been how to balance the twin objectives of using the Nigerian tax system to boost investment and industrial activities, and at the same time, increase revenue generation for the government and boost social development. 
Samuel and Tyokoso (2014) opined that the mobilisation of resources for public expenditure is more important as a purpose of taxation than provision of tax concessions and incentives for industrialisation. This position can only stand the test of time in the long run, and not in the short run, as most developing countries need to develop their tax base by boosting industrialisation. However, the regular feature in Nigeria has been that government tax agencies have focused efforts mainly on increasing revenue for the government at the expense of boosting industrial activities. Even though, the government needs more funds to provide infrastructure for economic development, but funds, which are partly sourced from taxes, can only be generated from the profits of increased number of vibrant and well-established firms. As such, government need to prioritise the need to provide and implement friendly tax environment using tax incentives and reduction of tax burdens, to boost investment and industrial activities, before reaping the benefits of industrial growth and increased profits.

\subsubsection{Oil Tax Revenue}

According to Yahaya and Yusuf (2019) oil tax revenues are revenues that arise from taxes on incomes and profits of oil producing companies operating in Nigeria. Over the years, the major source of revenue to the Nigeria government is oil revenue. It has contributed over half of the total revenue annually up to $85 \%$ for the government to neglect the non-oil sector (Okezie \& Azubike, 2014. Oil revenue is large but unstable, which make the size of government programs to change in response to fluctuations in prices of crude oil sales in the international oil market. Evidence showed that funds available for distribution among federal, state and local governments in Nigeria have being on decrease in recent time as a result of decline in oil price (Afuberon \& Okoye, 2014). According to Offiong (2016), the Petroleum Profit Taxation was introduced in Nigeria as early as 1959 under the Petroleum Profit Tax Act of 1959 (No.15) for taxation of oil companies engaged in upstream operations. Since its introduction, this act has been severally amended to keep it in tune with Nigerian government requirement of raising sufficient revenue for the government. It was first amended in 1967, then in 1970 and 1973, and subsequently in 1979. It relates to rents, royalties, margins and profit-sharing elements from oil mining, prospecting, and exploration leases. It covers oil and gas exploration and is complemented by two contractual agreements in operation, the Joint Operating Agreement and the production sharing contracts, between international oil companies and the Nigerian National Petroleum Company. To control the growth of the oil and gas sector and thus boost future revenue streams, the Federal Government introduced incentives in the taxation for gas exploitation, gas development, and gas utilisation activities (CITN,2014). While, gas exploitation and development activities are taxed under the Petroleum Profit Tax Act, gas utilisation activities are taxed under the provision of Company income Tax Act. The incentives for the upstream activities range from tax holidays, deduction of operating and capital expenditures, capital and investment allowances, to exemption from import duty and VAT. The downstream operators equally enjoy similar incentives and are taxed under the provisions of Company income Tax Act.

\subsubsection{Non-Oil Tax Revenue}

This publication is licensed under Creative Commons Attribution CC BY

http://dx.doi.org/10.29322/IJSRP.11.10.2021.p11829
Non-oil tax revenue is revenues from direct and indirect taxes paid by other sectors of the economy other than the oil sector (Yahaya \& Yusuf, 2019). Non-oil income in Nigeria is more integrated into tax revenue sources. From 2016 to 2019, Non-oil income in Nigeria was progressive. It increased from N2, 693.9 Billion in 2016 to N5, 536.66 Billion in 2019 (CBN Statistical Bulletin, 2019). In 2019, non-oil revenue composition was Value Added Tax 25.1\%, Customs and Excise Duties 17.9\%, Corporate Tax $35.7 \%$, Federal Government Independent Revenue $10.9 \%$ and forms of taxes 11.1\% (CBN Annual Report, 2019). The progressive report is a piece of evidence that tax revenue is very pivotal in driving an economy, especially an emerging market.

Company Income Tax: Company Income Tax (CIT) is levied on the profits made by companies operating in Nigeria, except those companies engaged in petroleum exploration activities. In the period before 1992, Company income Tax rates were on the increase, which affected savings and investment. The period after 1992 witnessed measures by government to reduce. Company income tax rates and attract more tax payers into tax net. Government took measures year after year to affect this. The rate of Company Income Tax was reduced from 45 percent in 1970 to 40 percent in 1987 , and to 35 percent in 1992, and further to 30 percent in 1996, till date. There has been also 20 percent concessionary rate from 1996 for companies engaged in agricultural and other activities, with turnover of not more than N1million. Rates for granting of Capital Allowances were continually adjusted to be in tune with economic realities (Somorin, 2015).

In addition, the government scrapped the Excess Profit Tax in 1991 as well as the Capital Transfer Tax in 1996. However, the imposition of minimum tax on companies that incur loss or little profit in any year of assessment has been counterproductive. The computation of the minimum tax on assets and capital, amounts to paying tax out of capital, and not out of profits, and has been counterproductive. The introduction of the Education Tax at 2\% (percent) on assessable profit of companies in 1993 effectively increased the rate of Company Income Tax, though the tax is computed separately and on a different basis. This tax has been part of the multiple taxes being frowned at by investors, because it has increased their burden and has been a disincentive to investment effort (Somorin, 2015).

\section{Capital Gains Tax (CGT)}

According to FIRS Act. 2014 (as amended), Capital Gain Tax (CGT) is a tax levied on the profit obtain from disposal or exchange of certain kinds of assets. In Nigeria, CGT is $10 \%$ of the profits from sale of qualifying assets. In addition, the tax authorities provide guidelines for determining what can be deducted from the sales proceeds before arriving at the capital gains. Also chargeable expenses must be deducted from the proceeds before arriving at the net proceeds. It includes selling expenses on costs of advertising and marketing, professional fees, such fees or brokerage paid to Estate Agents, Solicitors, Surveyors, Accountants, Estate Valuers, commissions and others; cost of refurbishing or improving the assets before being sold. However, when assets are sold as stocks or in ordinary course of business, their profits are not subject to CGT but to corporate tax of $30 \%$. 
Under CGT Act CAP C I LFN 2004; chargeable assets include all forms of property whether or not situated in Nigeria and those items exempted from CGT are those arising from disposals of decorations awarded for valour and gallantry conducted, life insurance policy, government securities, stocks and shares. Hence, gains shall not be chargeable if it accrues to some organisations provided the gain is not derived from any disposal of any asset acquired in connection with any trade carried on by the organization such as charitable or educational institutions, friendly society, cooperative society and trade unions (FIRS, 2004).

In subsequent amendments the government extended the tax to cover chargeable assets disposed by any individual living in Nigeria. The FIRS collects from companies on behalf of the Federal government while the State Internal Revenue Service collects from individuals on behalf of each state government. This tax has been inconsequential in the revenue generation of the government, due to a number of problems such as clumsy process of determining taxable gain, scarcity of records and disclosures, and complex provisions of the act (Somorin, 2015).

Value added tax (VAT): Value added tax (VAT) was introduced in 1994 to replace the sales tax. This is a type of consumption tax that is placed on a product whenever value is added at a stage of production and at final sale. The collection of value-added tax (VAT) in Nigeria is regulated by Value-added tax Act, 1993 as amended to date, and levied originally on 17 categories of goods and 24 categories of services. Value added tax (VAT) has been designed to resolve the problems associated with the former Sales Tax system, such as narrow tax base, cascading and increased rate of evasion. VAT has been excluded from Federal jurisdiction by the 1999 constitution, though it is enforced by Federal legislation. It is a consumption tax levied at the rate of 5 percent, up to January 31, 2020 and 7.5 percent (Finance Act 2020) effective February $1^{\text {st }} 2020$, on cost price of taxable persons, who are expected to add this amount to the price they will charge their customers, for collection and further remittance to relevant tax authorities on monthly basis. It adopts input-output tax mechanism, and is a multi-stage tax.

Personal income tax: Personal income tax is based on Pay as you Earn (PAYE) that is the tax payable depends on how much is earned by the tax payer. It is a direct tax levied on income of individuals. The Personal Income Tax Act taxes the incomes of employees, all self-employed people and individuals. The problem has been that this tax, so far, has been applied on employees in the formal sector on the basis of "Pay As You Earn" system, and sparingly applied on self-employed people who earn more than the employees. This has created a lot of inequity in the application of the tax laws, and has reduced the base for increased revenue to government. (Obatola, 2014). Also, Oyebanji and Oyebanji (2017) stated that, the 2011 VAT amendments contain the provision that an employer who fails to deduct, or having deducted, fails to remit shall pay a penalty of an amount of 10 percent of the tax not deducted or remitted, in addition to act the amount of tax not deducted or remitted plus interest at the prevailing monetary policy rate of the Central Bank of Nigeria (Somorin, 2012).

Custom duties: Custom duties represents taxes levied on imports (and, sometimes, on exports) by the customs authorities of a country to raise state revenue, and/or to protect domestic industries from more efficient or predatory competitors from abroad. This is based on the value of goods imported. Customs duties is one of the oldest form of taxation in Nigeria, having been first introduced in southern Nigeria due to trading activities in the area in 1960. They come mainly in the form of import duties and are charged as a percentage of the value of imports, or as a fixed amount contingent on quantity. Import duties are the highest yielding indirect or expenditure tax in Nigeria. The levying of custom duties is guided by the provisions of Customs and Excise management Act of 1958 as amended to date. At the early stages, customs duties were as high as 300 percent, but currently, the rates range between $2 \%$ to $75 \%$ (Durack, 2017).

Excise duty: Excise duties are taxes levied on locally manufactured goods and services. Excise duties was first introduced in southern Nigeria due to trading activities in the area in 1960. The levying of custom duties is guided by the provisions of Customs and Excise management Act of 1958 as amended to date. At the early stages, customs duties were as high as 300 percent, but currently, the rates range between 2 and 75 percent. The tax is administered by the Nigerian Customs Service (NCS). Excise duties are the form of import duties and are charged as a percentage of the value of imports, or as a fixed amount contingent on quantity. Import duties are the highest yielding indirect or expenditure tax in Nigeria. (Dubravka, 2017).

\section{Stamp Duties}

Stamp Duties are taxes on transactions that usually result to conveyance documents concerning bills of exchange, land transfers, promissory notes, debentures, bonds, covenants and warrants. It is backed up by stamp duty Act of 1958, codified as laws of the Federation of Nigeria cap411. The tax is usually executed by the commissioner for Stamp Duties. They are made up of fixed duties and ad valorem duties. Fixed duties are fixed charges on documents being stamped irrespective of the value of the instrument such as payment receipt, bank notes, cheque leaf, guarantor forms, and proxy forms. Ad valorem duties vary in accordance with the value of the instrument. The ad valorem tax is charged as a percentage of the value of the transaction.

\subsection{Foreign (External) Debt}

External debt is the portion of a country's debt that is acquired from foreign sources both at bilateral and multilateral levels such as foreign corporations, government or financial institutions. The debtors can be the government, corporations or private households (Amassoma, 2016). Purwanto and Mangeswuri, 2011) posited that foreign loans or foreign debt are a portion of a country's total debt obtained from creditors from outside the country. This form of debt can be in the form of money obtained from private banks, governments of other countries, or international financial institutions such as the IMF and the World Bank, or a number of funds borrowed and obtained from other countries. Similarly Kiminyei (2014), posits that debts are incurred by government through borrowing in the domestic and international markets to finance domestic investment in infrastructural and industrial development, social services and general development of a nation's economy. Similarly, Ateyah (2017) asserted that debt results from funds borrowed either from the local banks/country (internally) which is known as domestic debt or foreign debt or loan sourced from international market or 
multilateral agencies such as the World Bank, Africa Development Bank, or the Islamic Development Bank, and bilateral agencies such as the China Exim Bank, the French Development Bank, or the Japanese Aid Agency to finance domestic investment. Further, Amenawo and Hodo (2017) asserted that a number of reasons can be ascribed to how Nigeria's public debt became unmanageable which include but not limited to; the desire to accelerate economic growth and development. They also noted that in the 1970s, Nigeria operated ambitious development plans which assumed that the huge resource inflow from crude oil would be sustained but by the late 1970s, due to the first oil crisis, the momentum of project implementation could not be sustained. However, Nigeria was considered to be under borrowed then, and with dwindling oil revenue, the country resorted to external borrowing to accelerate the pace of development. Ogunjinmi, 2019 also stated that Nigeria is a monoproduct economy and it started experiencing public debt problem in the 1980s when her external debt position worsened. This situation led to the inability of Nigeria to generate the needed fund from oil and tax revenue to service the debt owed international creditors. To carry out production activities, Nigeria resorted to borrowing. These borrowings were meant to supplement the domestic savings (Ogunjimi, 2019).

\section{Theoretical Review}

This study is anchored on Laffer's theory (1974), Wagner (1883) theory and Myers'(1977) Debt overhang theory. The Laffer theory on taxation which states that $100 \%$ tax rate raises no revenue in the same way that a $0 \%$ tax rate raises no revenue. This is because at $100 \%$ rate, there is no longer incentive for a rational tax payer to earn any income, thus, the revenue raised will be $100 \%$ of nothing. It therefore means that there must be at least one rate in between where tax revenue would be a maximum. Similarly, Nwaobia in Nwachukwu, Ogundiwin and Nwaobia (eds.) (2015) posits that increasing tax rate beyond a certain point will become counter-productive for raising further tax revenue because of diminishing returns. Also, Kiminyei (2014) supported Laffer theory through his findings that public debt responds to both tax revenue and government expenditure particularly in the long run positively. Eboigbe and Idolor (2015) supports Wagner theory through their findings which showed that there is a positive relationship between debt stock (domestic and external debt) and public investment, meaning that an increase in debt stock will lead to increase in capital expenditure and public investment in turns. Myers (1977) propounded the theory of debt overhang which was established on the principle that if the level of debt will exceed the country's capacity to refund with some imminent likelihood, expected debt service is anticipated to be an increasing function of the country's economic growth level (Adedoyin et al., 2016). Krugman (1988) posits that debt overhang theory indicates the probability that in the future, debt will surpass the country's capability to repay as estimated debt-service costs will decrease further domestic and foreign investment because the expected rate of return from the productive investment projects will be very low to support the economy as the significant portion of any successive economic growth will accrue to the creditor countries. Monogbe (2016) opined that the failure of the current generation to service the acquired loans will lead to a greater debt burden for the upcoming generation.

\section{Empirical Review}

Ajayi and Oke (2012) in their study investigated the effect of the external debt burden on economic growth and development of Nigeria using regression analysis of OLS on secondary data sourced from Central Bank of Nigeria (CBN) Economic and Financial Review, and found that debt service obligation should not be allowed to rise more than foreign exchange earnings and that the loan contracted should be invested in profitable venture to generate a reasonable amount of money for debt repayment. Also, Ohwofasa, Nana and Kumapayi (2012) examined the effect of external debt management and macroeconomic performance of the Nigerian economy using Ordinary Least Squares (OLS) technique for data analysis and their findings reveal that the impact of external debt, debt service payment and balance of payment (BOP) on per capital income is negative while foreign direct investment has a positive influence on per capital income. Also Iliya and Tahir (2017), in their study examined the impact of external debt on Nigeria's economic growth using VAR, Cointegration and VECM Approach. Data were analysed employing Augmented Dickey Fuller (ADF) unit root test. Results indicate that external debt service payment had a long-run significant but negative relationship with real gross domestic product while Exchange Rate had a positive although insignificant, relationship with RGDP it was also found that exchange rate fluctuation had positive impact on the Nigerian economy while external debt service payment had significant negative impact on the same economy. Stephen, Mohanty and Fabrizio (2011) examined the real effects of debt in eighteen (18) Organization for Economic Co-operation and Development (OECD) countries from 1980 to 2010. OLS Regression analysis was employed and their findings support the view that, beyond a certain level, debt is a drag on growth. Also, Nazim (2016) examined the relationship between government revenue and government expenditure in Malaysia using Linear regressions with Ordinary Least Squares (OLS) and found out that although majority of the government revenue is from direct tax, the government spending only varies due to change in indirect tax revenue and non-tax revenue. Samuel and Tyokoso (2014) investigated the relationship between taxation and revenue generation of selected States in Nigeria. The methods of data collection in the study are primary and secondary and regression analysis via SPSS version 17.0.were used. The results showed that taxation has a significant contribution on revenue generation, Gross Domestic Product (GDP) while tax evasion and tax avoidance have a significant effect on revenue generation in Nigeria. Also, Afuberoh and Okoye (2014) examined the impact of taxation on revenue generation in Nigeria. The testing of the hypotheses of the study was done using regression analysis. The research discovered among others that, taxation has a significant contribution to revenue generation. Dubravka (2017) investigated control of state audit in budget revenue realization and tax revenue dynamics. An induction method which defined certain regularities based on empirical phenomena or processes was used and it was found that taxes are an important instrument of economic policy that can be applied to influence the achievement of certain targets at the national level, from income distribution, price stability, and creating greater employment. 
Alena and Veronika (2018) investigated tax revenue in the context of economic determinants using three models of regression analysis; the pooling model, the fixed effects model and the random effects model and found that, there is strongest correlation between tax revenue and employment rate and between foreign direct investment and gross domestic product.

Drawing from the results of these studies, this study hypothesized that:

$\mathrm{Ho}_{1:}$ Tax revenue has no significant effect on foreign debt.

\section{MethodOLOGY}

This study employed Ex-post-facto design to investigate the relationship between tax revenue and foreign debt in Nigeria. Also, this design has been extensively used in related empirical studies as Adegbie et al., (2020), Asaolu et al., (2019), Jabir et al., (2020); Ogba, Park, and Nakah, (2018), Omodero, and Ehikioya (2020), and Yahaya and Yusuf (2019). The study made use of existing data derived from the Central Bank of Nigeria (CBN) statistical bulletin and Federal Inland Revenue Service (FIRS) annual reports and accounts between 1981 and 2019 to consider the nature of past relationship between the variables, establish the current impact and develop a predictive (regression) model to project the degree of effect of the tax revenue on the foreign debt.

\section{Method of analysis}

The study employed descriptive statistics to understand the nature of the time series data and also to determine the stability of the variables expressed in terms of mean, median, mode, standard deviation, kurtosis, skewness, Jacque-Bera as well the unit root test stationary at 5\% critical level. It also adopted the Robust Ordinary least square regression analysis for the estimation of the

relationship between tax revenue proxied by oil-tax revenue and non-oil tax revenue and foreign debt.

\section{Model Specifications}

For the purpose of this study, the dependent variable is presented as foreign debt (FD) while the independent variable, that is tax revenue (Tax Rev) is proxied by oil tax revenue (OTR) and non-oil tax revenue (NOTR). The functional relationship and models for this current study are specified as follows:

\section{Functional Relationship}

$\mathrm{Y}=\mathrm{f}(\mathrm{X})$

$\mathrm{Y}=\mathrm{f}(\mathrm{X})$

$\mathrm{Y}=$ Dependent Variable, that is, Foreign Debt (FD)

$\mathrm{X}=$ Independent Variable, that is, Tax Revenue (Tax Rev)

Thus, the specific functional relationships were:

$$
\begin{aligned}
& \mathrm{Y}=\mathrm{y}_{1} \\
& \mathrm{X}=\mathrm{x}_{1, \mathrm{x}_{2}} \\
& \mathrm{y}_{1}=f\left(\mathrm{x}_{2}, \mathrm{x}_{2}\right) \\
& \mathrm{y}_{1}=\quad \text { Log of Foreign Debt (LFD) }
\end{aligned}
$$

\section{The Model}

$\mathrm{LFD}_{\mathrm{t}}=\alpha_{0}+\beta_{1} \mathrm{LOTR}_{\mathrm{t}}+\beta_{2} \mathrm{LOTR}_{\mathrm{t}}$

Where: $\alpha_{0}$ is the constant

$\mathrm{LFD}_{\mathrm{t}}$ represents the Log of Foreign Debt in time $\mathrm{t}$

LOTR- Natural log of tax oil revenue;LNOTR-Natural log of Non-oil tax revenue

t represents time; and $\mu_{1}$ is the error term which are other variables not included in the model

$\beta_{1}-\beta_{2}$ are the co-efficient

\section{ANALYSIS, RESULTS AND DISCUSSIONS 4.1 Diagnostic Tests}

\section{Table 4.1 Heteroskedasticity Test}

Heteroskedasticity Test: Breusch-Pagan-Godfrey

\begin{tabular}{llll}
\hline \hline F-statistic & 0.205392 & Prob. F(2,36) & 0.8153 \\
Obs*R-squared & 0.439996 & Prob. Chi-Square(2) & 0.8025 \\
Scaled explained SS & 0.222520 & Prob. Chi-Square(2) & 0.8947 \\
\hline
\end{tabular}

\section{Source: Researcher's Computation, (2021)}

Breusch-Pagan-Godfrey Test was conducted for Heteroskedasticity; that is testing for the consistency of the variations in the residuals of the model over the period " $t$ ". The result with the $\rho$-value of 0.815 as depicted in Table 4.1 being greater than 5 per cent chosen level of significance is a reflection of consistencies in the differences of the residuals of the model across the period " $t$ " that is the residuals of the model are stable over time and it is appropriate for estimating the model.

\section{Normality Test}




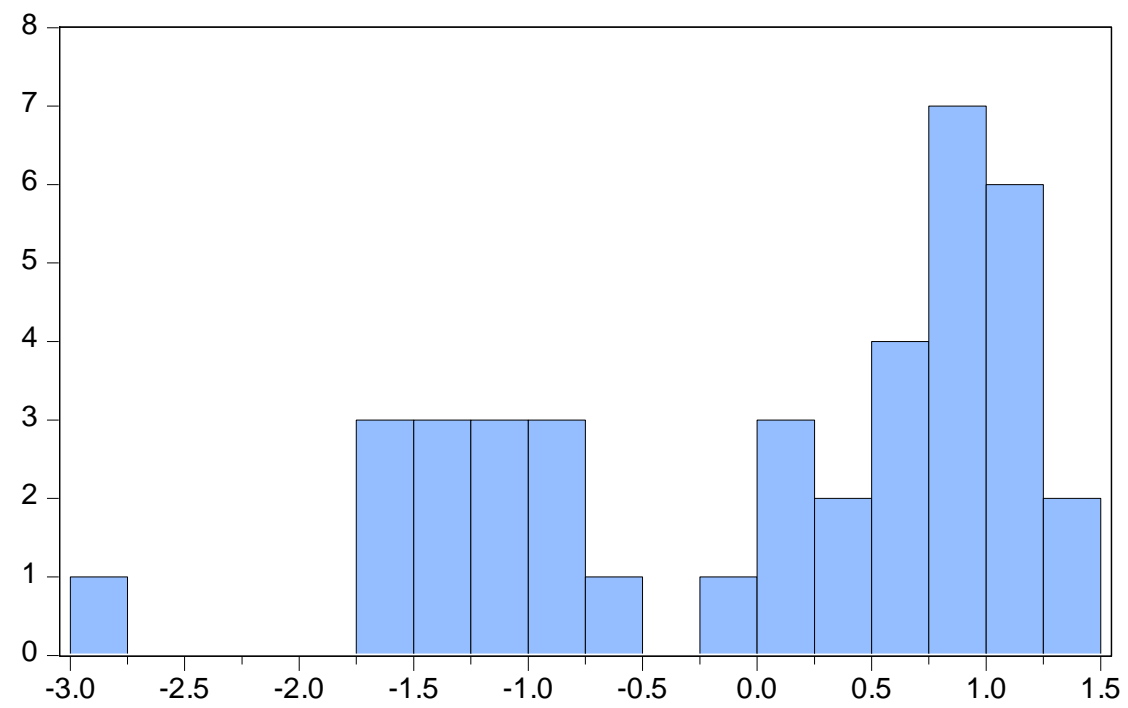

\section{Series: Residuals \\ Sample 19812019 \\ Observations 39}

Mean

$-6.38 \mathrm{e}-16$

Median

0.422454

Maximum

1.350586

Minimum

$-2.752071$

Std. Dev.

1.095553

Skewness

$-0.638059$

Kurtosis

2.187065

Jarque-Bera

Probability

3.720179

0.155659
The probability of the Jacque-Bera test of the model was used to estimate the normality test. The probability value of the JacqueBera (0.156) which is above 5\% significance level supported the null hypothesis of the test and thus, confirmed the normality of the model, which implies that the series is normally distributed.

\section{Table 4.2 Stability Test}

Ramsey RESET Test

Equation: UNTITLED

Specification: LFD LOTR LNOTR C

Omitted Variables: Squares of fitted values

\begin{tabular}{llcc}
\hline \hline & Value & Df & Probability \\
\cline { 2 - 4 } t-statistic & 5.663531 & 35 & 0.0000 \\
F-statistic & 32.07558 & $(1,35)$ & 0.0000 \\
Likelihood ratio & 32.07558 & 1 & 0.0000 \\
\hline \hline
\end{tabular}

\section{Source: Researcher's Computation, (2021)}

The Ramsey RESET Test is used to test the stability of the model and it's suitability for estimating a long run decision. The result as shown in Table Table 4.1. implies with probability value of 0.000 indicates that the parameters of the model exhibit structural instability over the period of study.

\section{Table 4.1.3 Serial Correlation LM Test}

Breusch-Godfrey Serial Correlation LM Test:

\begin{tabular}{llll}
\hline \hline Obs*R-squared & 0.759969 & Prob. Chi-Square(2) & 0.3833 \\
\hline \hline
\end{tabular}

\section{Source: Researcher's Computation, (2021)}

The Breusch-Godfrey Serial Correlation LM Test was carried out to determine the existence of associations among the coefficients of the model and its residuals and the result presented in Table 4.3. Unhealthy association result to the error terms being smaller than expected and the co-efficient of determination being higher than normal. The statistics derived with $\rho$-value $=0.383$ supports the null hypothesis which states that there is no serial correlation among the coefficients of the model at 5 percent significant level. The review of the results of all the diagnostic tests carried out showed that the model is linear, homoscedastic, not serially correlated, normally distributed, but exhibited instability problem; therefore, the long run equation was estimated using generalized (Robust) least square regression method of analysis and the result presented in Table 4.4

4.2.5. Regression Result for Hypothesis 
Table 4.4. Results of the Regression Analysis (Hypothesis Three)

\begin{tabular}{|l|l|l|l|l|}
\hline Variables & Coefficient & Std. Error & t-Statistic & Prob. \\
\hline LOTR & 0.443 & 0.420 & 1.055 & 0.291 \\
\hline LNOTR & 0.210 & 0.415 & 0.506 & 0.613 \\
\hline C & 2.543 & 0.689 & 3.689 & 0.000 \\
\hline R-squared 0.491 \\
\hline Adjusted R-Squared: 0.463 \\
\hline \multicolumn{4}{|l}{} \\
\hline
\end{tabular}

Source: Researcher's Computation, (2021)

\section{Long Run Estimation}

$\mathrm{LFD}_{\mathrm{t}}=2.543+0.443 \mathrm{LOTR}_{\mathrm{t}}+0.210 \mathrm{LNOTR}_{\mathrm{t}}+\mu_{\mathrm{t}}$

The result of the Generalized (Robust) Least Square regression estimation test as shown in Table 4.2.1. reveal that change in oil tax revenue and non-oil tax revenue positively but insignificantly affect the change in foreign debt in Nigeria at 5\% level of significance which implies that the more the revenue generated through both oil and non-oil sources, the more the foreign debt incurred by Nigeria government. The coefficients of 0.443 and 0.210 evidenced that a change in OTR and LNOTR will yield a direct change of 0.443 and 0.210 in FD. The value of the adjusted R-Squared of 0.463 explains the causal-effect relationship of the combined change in OTR and NOTR with FD. It implies that a combined change in both oil and non-oil tax revenue could explain $46.3 \%$ incremental change in FD while the remaining $53.7 \%$ changes in FD is as a result of other factors outside the scope of model three of this study. The implication is that OTR and NOTR could not explain about 54\% variation in FD. Based on the $\rho$-value of the Rn-squared -statistic (0.00) which is less than the chosen significance level of 0.05 , this study hereby conclude that tax revenue significantly impacted on foreign debt (FD). The study thus rejects the null hypothesis which states that "tax revenue has no significant effect on the foreign debt of Nigeria; while the alternate hypothesis is accepted, that is tax revenue significantly affects foreign debt in Nigeria.

\section{Discussion of the Results}

The findings of this study align with the assertion of Ekeruche (2021) which asserted that the country tends to face liquidity crisis as the price of oil which contributes $50 \%$ of consolidated government revenue and $80 \%$ of exports has fallen considerably too, and economic activities have been all time low. The most recent estimates show that government revenue will decline from $8 \%$ to $5 \%$ of GDP between 2020 and 2021, with the chronic shortage of finance likely to cause the Federal Government to spending sizeable portion of its revenue on interest payments in 2021. As a result, borrowing is inevitable.

The insignificant positive impact of tax revenue on national debt (non-oil on domestic debt and oil on foreign debt) appears to agree with the report of the World Bank in (2019), that Nigeria has not generated enough revenue from taxes as compared to other African countries as tax revenue-GDP of Nigeria was 5.7\%, which is lower than the $17.2 \%$ average for 26 African countries by $11.5 \%$, and also lower than the $22.8 \%$ average for the Latin American countries and the OECD average of $34.2 \%$ (OECD, 2019). Moreover, the logical and rational expectation should be an inverse relationship between tax revenue and foreign debt. That foreign debt is increasing following increase in tax revenue (as implied in our result) not only proves that tax revenue is not sufficient enough to cushion the rise in the nation's debt profile especially foreign debt but also that generated tax revenue may not have been properly utilized in meeting the country's expenditure needs.

\section{CONCLUSION AND RECOMMENDATION}

This study concludes that tax revenue has not improved the country's foreign debt profile. Hence, the quantum of foreign debt in Nigeria is not determined by its tax revenue. Therefore, the study recommends that Federal Government should vigorously pursue the task of diversification of the economy with appropriate policy mix and setting of achievable measures in exploring several opportunities available in generating revenue in addition to taxes. Generated tax revenues should be judiciously utilized to reduce poverty, improve the quality of human resources, preserve natural resources, develop the latent economic potentials and production capabilities of individual communities, companies and governments, in order to expand tax net, generate more revenue for governments and thereby place less reliance on acquisition of foreign debts.

\section{REFERENCES}

[1] Adedoyin, L.I., Babalola, B.M., Otekinri, A.O., \& Adeoti, J.O. (2016) External debt and economic growth: Evidence from Nigeria. Acta Universitatis Danubius Economica, 12(6), 179-194

[2] Afuberoh, D. (Mar. 2014). The impact of taxation on revenue generation in Nigeria: A study of federal capital territory and selected states. International Journal of Public Administration and Management Research, 2(2), 22-47.

[3] Ajayi, L. B. (Jun. 2012). Effect of external debt on economic growth and development of Nigeria. International Journal of Business and Social Science, 3(12, Special issue), 297-304.

[4] Alena, A. \& Veronika P. (2018). Tax revenue in the context of economic determinants. Montenegrin Journal of Economics, 14(1), 133-141.

[5] Amassoma, D. (2011). External debt, internal debt and economic growth bound in Nigeria using a causality approach. Current Research Journal of Social Sciences, 3(4), 320-325.

[6] Amenawo, I. O. (2016). Public debt shocks and public goods provisioning in Nigeria: implication for national development. Journal of Economics and Sustainable Development, 7(18), 1700-2855.

[7] Andi S. (2019). The effect of tax revenue, investment and foreign debt on poverty level

[8] Advances in Social Sciences Research Journal - No.1 DoI:10.14738/assrj.61.5964.

[9] Asagunla, T. M. \& Agbede M. O. (2018). Oil revenue and output growth in Nigeria. IIARD International Journal of Economics and Business Management, 4(6), 65-74. 
[10] Ateyah, A. (2017). The impact of public expenditure and public debt on taxes: A case study of Jordan. Accounting and Finance Research, 6(3), 1023.

[11] Bakare, A.S. (2011). The macroeconomic impact of foreign aid in SubSaharan Africa: The case of Nigeria. Business and Management Review, $1(5), 24-32$

[12] CBN.(2017). Statistical Bulletin. Abuja. Federal Government Printer

[13] Chartered Institute of Taxation of Nigeria. (2014). Nigerian Tax Guide \& Statutes. Lagos: The CIBN Press Limited.

[14] Dubravka, M. (2018). Control of state audit in budget revenue realisation and tax revenue dynamics. Proceedings of the 8th International Scientific Conference Finance and Performance of Firms in Science, Education and Practice, (pp. 603-616). Croatia.

[15] Eboigbe, S. U. (2015). External debt and public sector investment: The Nigera perspective.

[16] Iliya, A. T. (2017). The impact of external debt on Nigeria's economic growth (1980 -2014).

[17] VAR, Cointegration and VECM Approach. Journal of Economics and Sustainable Development, 8(18), 140-151

[18] Ijirshar, V.U., Joseph, F., \& Godoo, M. (2016). The relationship between external debts and

[19] Economic growth in Nigeria. International Journal of Economics \& Management Sciences, 6(1), 1-5. doi:10.4172/2162-6359.1000390.

[20] Focus Economics (2019). External debt percentage (\%) of GDP. Retrieved on June 9, 2019 from

[21] https://www.focus- economics.com/economic-indicator/external-debt.

[22] Federal Inland Revenue Service, (2004). Guide for new investors. Firs.gov.ng/ capital gain tax.

[23] Krugman, P. (1988). Financing vs forgiving a debt overhang. Journal of Development

[24] Economics, 29(3), 253-268.

[25] Kehinde J. A.; Olanike B.; Oni E. \& Achukwu M. (2015). Public debt and private investment in Nigeria. American Journal of Economics, 5(5), 505507.

[26] Kiminyei, F. K. (2018). Tax revenue and government expenditure in Kenya. International Journal of Economics \& Management Sciences, 7(5), 4172/2162-6359.

[27] Molle, AI, Pangemanan, SS, \& Sabijono, H. (2014). Analysis of Factors Affecting Personal

[28] Taxpayers' Income Tax Receipts at Manado Primary Tax Office. Journal of Economic Research, Management, Business and Accounting, 2 (4).

[29] Myers, S.C. (1977). Determinants of corporate borrowing. Journal of Financing Economics, 5(2), 147-175.

[30] Monogbe, T.G. (2016). Intergenerational effect of external debt on performance of the Nigeria

[31] Economy. NG-Journal of Social Development, 5(2), 51-65.

[32] Nwobia, A.N. (2015). Theories in Accounting Research. (Anthology of Theories and their Applications in Social and Management SciencesJ.N.Nwachukwu \& A.O.Ogundiwin 1ST Ed)s 27-77. Lagos Jamiros Link.
[33] Obatola, O. S. (2014). The Rudiments of Nigerian Taxation. Lagos. ASCO Publishers.

[34] Odo, S. I. Igberi C. O. \& Anoke C. I (2016). Public debt and public expenditure in Nigeria. A causality analysis. Research Journal of Finance and Accounting, 7(10), 27-38.

[35] Ohwofasa, B. O. (2012). External debt management and macroeconomic performance of the Nigerian economy. Journal of Economics and Sustainable Development, 3(13), 58-62.

[36] Offiong, U. B. (2016). Petroleum Profits Tax in Nigeria (second edition). Lagos: The CIBN Press Limited.

[37] Ogba, L. J., Park, I., \& Nakah, M. B. (2018). The impact of non-oil revenue on economic growth in Nigeria. International Journal of Advance Research in Accounting, Economics and Business Perspectives, 2(1), 1-14.

[38] Ogunjimi, J. A. (2019). The impact of public debt on investment: evidence from Nigeria. DBN Journal of Economics and Sustainable Growth.

[39] Olurounbi, The African Report, 28 December 2020 17:09).

[40] Omodero, C. O., \& Ehikioya, B. I. (2020). Oil and non-oil revenues: assessment of contributions to infrastructural development in Nigeria. Journal of Management Information and Decision Sciences, 23(5), 638-648.

[41] Oyebanji, J. O. (2017). Principles and practice of taxation in Nigeria. Ibadan: Frontline Publishers.

[42] Oyedele, T. (2015). Insights on taxation and fiscal policy. London: CPI Group (UK) Limited.

[43] Samuel, S. E. (2014). Taxation and revenue generation: an empirical investigation of selected states in Nigeria. Journal of Poverty, Investment and Development - An Open Access International Journal, 4, 102-114.

[44] Stephen, G. C. (2011). The real effects of debt. BIS Working papers, 352.

[45] Tajudeen, E. (2012). External borrowing and economic growth in Nigeria. Fountain Journal of Management and Social Sciences, 1(1), 01-09.

[46] Torki, M. A. (2016). Determinants of external debt in Jordan. An empirical study. International Business Research, 9(7), 116-123.

[47] Udeh, M.C. (2013). The impact of external debt on the Nigerian economy. Enugu, Nigeria:

[48] Caritas University.

[49] Uguru, L. C. (2016). The link between public debt and government expenditure pattern: The Nigeria experience. IOSR Journal of Business and Management, 18(1), 37-41.

\section{AUTHORS}

First Author - Nwaobia, A. N. (PhD., FCA)

nwaobiaa@babcock.edu.ng

Second Author - Ogundipe, S.A. (PhD., FCIB);

ogundipea@babcock.edu.ng

Third Author - Adejumo,O. (M.Sc, ACA)

rotimi4ever2007@yahoo.com. 